\title{
Age-related characteristics of lipid peroxidation and antioxidant defense system of ostriches (Struthio camelus domesticus)
}

\author{
V.M. Polishchuk, S.I. Tsekhmistrenko, S.A. Polishchuk, N.V. Ponomarenko, N.V. Rol, \\ S.V. Cherniuk, O.O. Cherniavskyi, O.A. Kuzmenko, N.M. Prysiazhniuk, V.M. Karaulna, \\ I.O. Lastovska, N.M. Fedoruk
}

\author{
Bila Tserkva National Agrarian University \\ 8/1 Soborna Square, Bila Tserkva, 09111, Ukraine \\ *Corresponding author E-mail: vitnik2007@ukr.net
}

Received: 19.12.2019. Accepted 15.02.2020

\begin{abstract}
We studied the intensity of lipid peroxidation (LPO) and the status of antioxidant system in blood of 6-60 months ostriches. We proved that specific functioning of the antioxidant system and the accumulation of lipid peroxidation intermediates characterized each period of ostrich life cycle. Thus, the period of puberty was accompanied by intensification of lipid peroxidation in ostrich blood serum and this was confirmed by a significant increase in the amount of TBA-reactive substances. This could be the consequence of the insufficient activity of enzymes of the antioxidant system (catalase, glutathione-S-transferase, glutathione reductase). The egglaying peak was characterized by the increased body metabolism, which caused the activation of free-radical oxidation. The concentration of lipid hydroperoxides and diene conjugates increased and the TBA-reactive substances did not change significantly. Antioxidant protection of the blood during this period was mainly caused by the significant concentration of ceruloplasmin and reduced glutathione due to the increased activity of glutathione reductase. We supposed that the period of puberty and intensive period of egg laying in ostriches should be referred as the periods of stress of metabolic processes with increased intensity of lipid oxidation, associated with the certain changes in ostrich physiological and functional state.
\end{abstract}

Keywords: Blood serum; Oxidative stress; Antioxidant; Lipid peroxidation; Antioxidant system enzymes; Ostriches; Struthio camelus domesticus.

\section{Introduction}

Modern poultry consider new species in order to increase production and expand its range. A rather new, but very promising industry, ostrich farming, is acquiring special development (Beregovij, 2012). In Ukraine, the ostrich production market is practically absent, so producers of ostrich meat can work with minimal competition with a smooth, uninterrupted sale mode.

The first African ostrich breeding farms appeared in 30-40 years of XIX century in South Africa (Cloete et al., 2008; Brand et al., 2018). At the beginning of the twentieth century, the number of ostriches kept in farms was about one million. However, after World War I, the demand for ostrich feathers fell sharply, which led to a complete decline in the industry. In the second half of XX century, the breeding of ostriches again gained popularity in Europe and the US. The ostrich business generates considerable income with minimal expenses since it is practically waste-free. The main products of ostrich farming are meat, skin, feathers, eggs, and fat. Agricultural breeding of ostriches was implemented in different countries, lile Australia, Belgium, Israel, Italy, Canada, New Zealand, Poland, France, and Sweden. However, the largest number of farms is concentrated in the Republic of South Africa (AlKhalifa \& Al Naser, 2014; Mahrose et al., 2016). Until 1917, there were 500 ostrich farms operating in Ukraine. Now there are about 60 of them. They are mainly concentrated in the western, central, and southeastern parts of the country (Nagorna, 2013).

The ostriches are very sensitive to the effects of various stress factors, namely feeding, keeping, care, health status (Minka \& Ayo, 2008; Vazquez-Galindo et al., 2013; Bejaei \& Cheng, 2014). From a physiological point of view, the deviations from optimal internal and external conditions will lead to the development of stress. For the limitation of stress effect, the homeostasis can be restored by the coordinated action of the hypothalamic-pituitary-adrenal system, autonomic nervous system and immune system. In poultry farming, four main types of stress are distinguished: technological, environmental, feed, and internal (Surai et al., 2019). Free radical oxidation processes play a special role in the development of stress. Free radicals - reactive forms of oxygen (ROS) are able to destroy the molecules of lipids, proteins, nucleic acids. About 200 billion free radicals are synthesized daily in physiological conditions in each cell (Fisinin et al., 2014). In the case of pathologies, this number increases significantly, which leads to the development of oxidative stress (Del Vesco et al., 2017; Rehman et al., 2018; Tsekhmistrenko et al., 2018). Thus, the adaptive changes occur, which are accompanied by the activation of enzymes of the antioxidant defense system, associated with an increase in the concentration of toxic metabolites. The accumulation of these compounds can lead to the development of oxidative stress due to an imbalance between the oxidative and antioxidant systems. However, consideration of the influence of reactive forms of oxygen only as a negative, damaging factor makes it impossible to comprehensively understand their significance in biological systems. Recent studies have contributed to a deeper understanding of the positive effects of ROS in cell proliferation and differentiation, synthesis of biologically active compounds, individual hormones, phagocytosis and apoptosis (Roy et al., 2017; Krylatov et al., 2018; Forrester et al., 2018; Tsekhmistrenko et al., 2018). 
The ostrich meat and eggs are very popular in many countries. These products, compared to other animals and poultry, have lower lipid and cholesterol levels, which is especially important for the people with cardiovascular disease (Magige et al., 2017). Therefore, ostrich meat is very valuable and useful dietary product. There is a lot of data on functioning of the antioxidant system of various bird species (Burlaka et al., 2013; Bastos et al., 2017; Del Vesco et al., 2017; Morosinotto et al., 2017; Wan et al., 2019; Fernye et al., 2018; Bityutskyy et al., 2019). Nevertheless, there are limited data characterized the state of antioxidant system of ostriches (Tsekhmistrenko \& Polishchuk, 2010, Jóźwik, et al., 2015, Ghasemi \& Hajkhodadadi, 2019). The functioning of the antioxidant system determines the level of the compensatory and adaptive response of the body under the conditions of the possible development of oxidative stress during transportation, preventive treatments, and rearrangement of animals and birds. This is especially true for ostriches, since the conditions of their maintenance are significantly different from natural. The determination of the age period, characterized by a decrease in the antioxidant status of the ostriches' organism, will allow correct correction of oxidative stress and reduce the risk of flare-up and progression of pathological conditions.

The purpose of our work was to investigate the age-specific characteristics of lipid peroxidation and the immune status in blood of Struthio camelus domesticus.

\section{Material and Methods}

The birds were kept in peasant open joint-stock company "Gaysinskiy enterprise on breeding case in animal husbandry", in village Gaysin, Vinnitsya region, Ukraine $\left(48^{\circ} 48^{\prime} 34^{\prime \prime} \mathrm{N}, 2^{\circ} 23^{\prime} 26^{\prime \prime} \mathrm{E}\right)$. We selected clinically healthy ostriches. We divided the birds into five groups (five heads each): the first - 6-month old, the second 9-month old, the third 18-month old (puberty), the fourth - 24-month old (the period beginning oviposition), and the fifth -60 -month old (the period of intensive oviposition). The blood were taken from the head veins (basilic) of the shoulder. To obtain serum, the tubes with whole blood was kept for one hour in a thermostat at $37^{\circ} \mathrm{C}$, then centrifuged at $3000 \mathrm{rev} / \mathrm{min}$ for $15 \mathrm{~min}$.

Biochemical studies of blood serum of ostriches were carried in interfaculty research laboratory of biochemical and histological methods of research of Bila Tserkva National Agrarian University (Ukraine). We studied the content of total lipids (TL) in blood plasma by the reaction with sulfurospirillum reagent using a standard set of reagents (Felisit-diagnosis, Ukraine). The intensity of lipid peroxidation (LPO) in serum were determined by the content of diene conjugates (DC) (Stalnaya, 1997), which are formed in the initial stages of LPO, lipid hydroperoxides (LHP), using ammonium thiocyanate (Romanova \& Stalnaya, 1977) and products reacting with 2-tabarro acid (TBA-RS) (Andreeva et al., 1988). The factor of antioxidant state was calculated by the formula (ADF) (Chevari et al., 1991).

The condition of antioxidant system (AOS) was evaluated by the level of activity of enzymes: superoxide dismutase (SOD; EC 1.15.1.1) (Chevari et al., 1985); catalase (CAT; EC 1.11.1.6) (Goth, 1991); glutathione peroxidase (GPx, EC 1.11.1.9) (Alam et al., 2013), glutathione reductase (GRD; EC 1.6.4.2) (Yusupova, 1989), glutathione-transferase (GSH; EC 2.5.1.18) (Habig et al., 1974), the contents of reduced glutathione (GSH) (Goryachkovskij, 1998), ceruloplasmin (CP; 1.16.3.1) (Ravin, 1961). The animals and the experiments were conducted in accordance with the provisions of "European Convention for the protection of vertebrate animals used for experimental and other scientific purposes" (Strasbourg, 1985), "General ethical principles of animal experimentation" adopted by the First National Congress on bioethics (Ukraine, 2001) (Ryeznikov, 2003). The results were processed statistically using Student's t-test by means of Statistica 6.0 software (StatSoft, Inc., USA).

\section{Results and Discussion}

The mechanisms of regulation of lipid balance and the state of redox processes in the body are closely interrelated. When LPO is activated, changes in the functional activity of the lipid components occur. The inhibition of the processes of free radical oxidation depends on the activity of the enzymes of the antioxidant defense system, a significant role in which SOD plays, because it provides enzymatic dissemination of the precursor of the active forms of Oxygen - superoxide radical (Surai et al., 2019). We registered that the activity of superoxide dismutase in the serum of ostriches changed during the study period. The blood of 6-month-old male birds had high SOD activity (Figure 1).

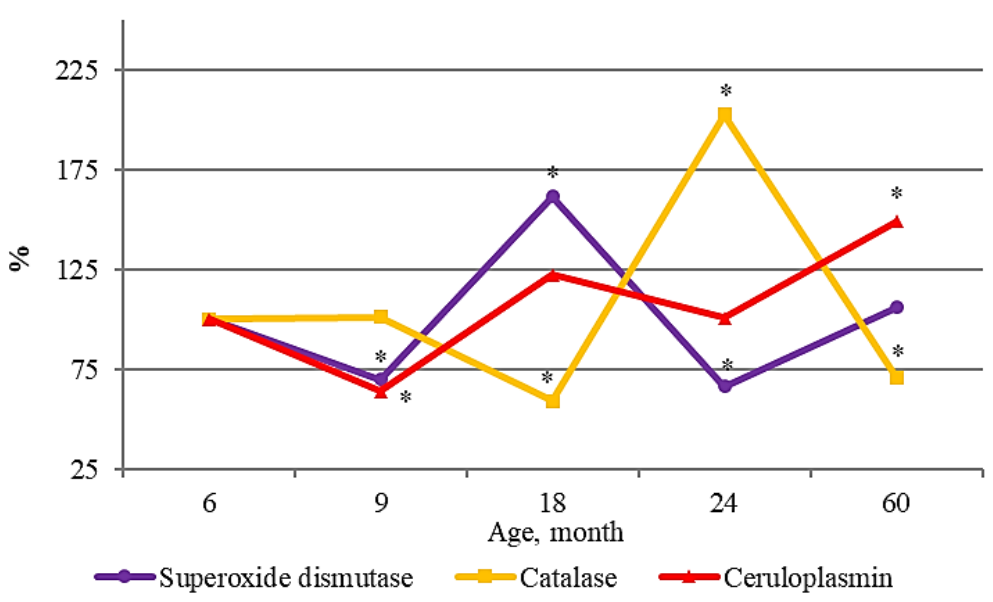

Figure 1. Age-related dynamics of antioxidant enzyme activity in ostrich blood serum. * - difference is significant compared to the 6-month-old birds, $\mathrm{P}<0.05$ (here and in Figures 4, 6).

During this period, a high concentration of DC and TBA-RS was observed. These changes, to some extent, can be explained by the large amount of total serum lipids that are the main substrate for lipid peroxidation (Figure 2). 


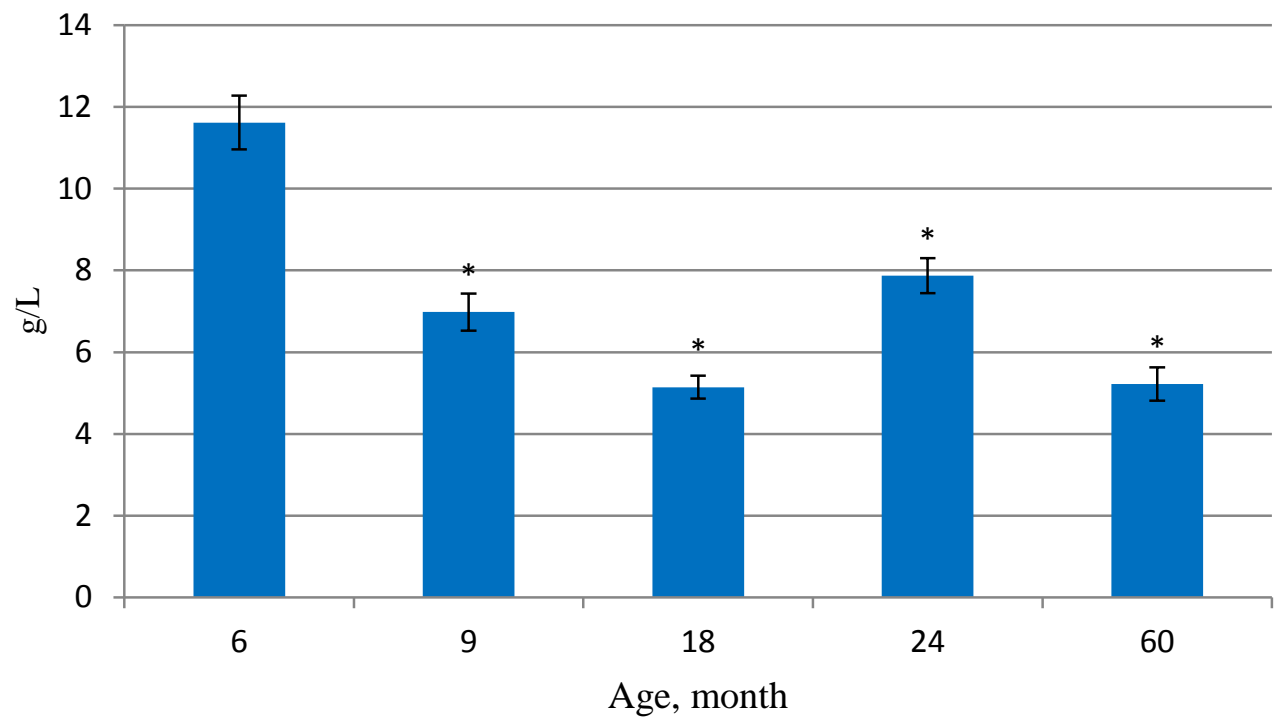

Figure 2. Content of total ostrich serum lipids. * Changes in the indicator relative to the previous stage of the study are likely, $P<0.05(M \pm m ; n=5)$.

The high activity of the enzyme was explained by the compensatory reaction of the body to the increase the content of primary and secondary products of lipid peroxidation. Subsequently (up to nine months of bird age) the enzyme activity decreases by $30.9 \%$. Such dynamics of SOD activity were probably caused by its interaction with free radicals, which was accompanied by a decrease in the content of lipid peroxidation products. Maximum SOD activity was recorded during the ostrich puberty period (18 months). This may indicate the activation of metabolic processes, in particular increasing of $\mathrm{O}_{2}$ demand, generation of reactive oxygen species, which intense SOD activity. We assumed that the effectiveness of protecting cells from ROS was determined not by the absolute values of enzyme activity, but by the ratio of their activity. We calculated the ratios between the activities of SOD/CAT $\times 100$, $\mathrm{SOD} / \mathrm{CP} \times 100, \mathrm{SOD} / \mathrm{GPx}$, SOD/GST, SOD/GRD, GPx+GST/GSH, GRD/GSH (Figure 3).

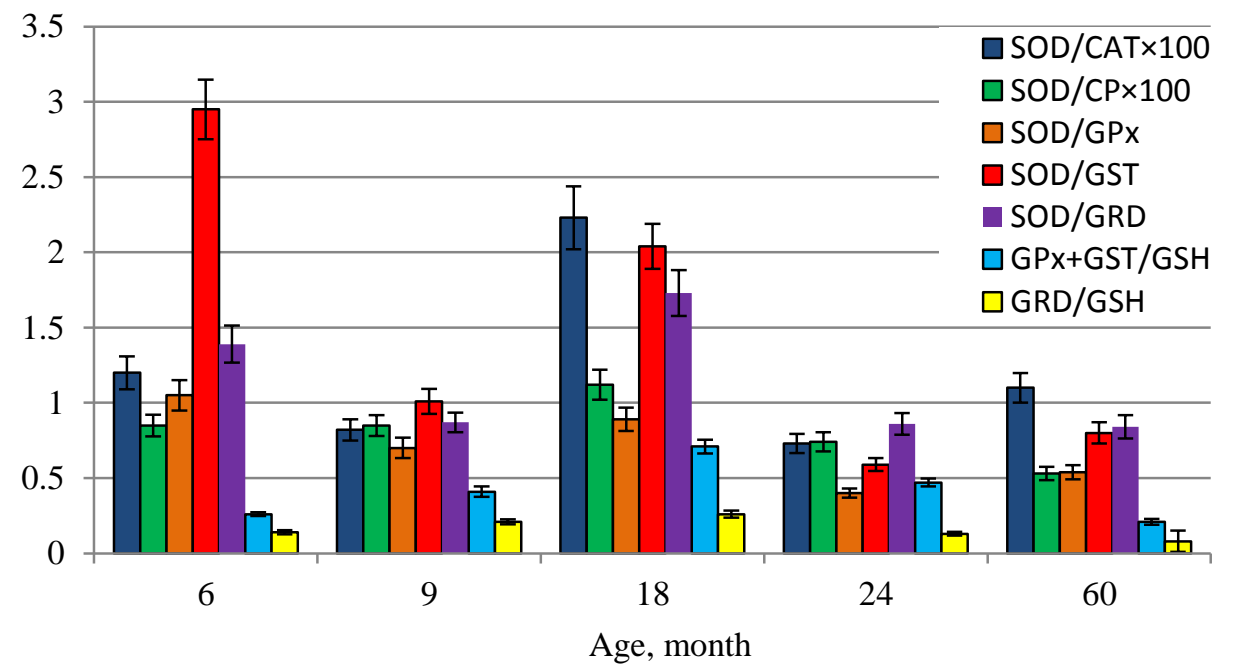

Figure 3. The ratio between activities of enzymes in blood serum of ostriches.

Birds in puberty stage had the high rate of SOD/CAT $\times 100$ activity. A similar trend observed in the ratio of SOD/CP $\times 100$, however, the lowest rate of enzymes SOD/GPx activity was observed in 24-month-old birds. We suggested that catalase was the main enzyme, which detoxified the excess of $\mathrm{H}_{2} \mathrm{O}_{2}$ in the serum of ostriches. The dynamics of catalase activity in ostrich blood serum differed in age from the dynamics of SOD activity, which implied the unequal role of individual AOS components at different stages of development. The CAT activity in the serum of 9-month-old birds virtually unchanged compared with the previous investigation period. Such changes may occur due to the inclusion in the mechanisms of the antioxidant responses of other components of the AOS. Proof of this is the increasing activity of GPx and GST in the serum of ostriches. Restored organic hydroperoxides, glutathione peroxidase prevented the accumulation of toxic products of lipid peroxidation, but did not provide its clearance. This function is performed by another glutathione enzyme system - glutathione-transferase, which also used intracellular GSH as a substrate (Surai et al., 2019).

The decrease in CAT activity in 18-month-old ostrich serum is offset by an increase in GPx activity. The activity of GST decreased significantly, which indicated the competition of two glutathione enzymes for GSH in the conditions of decrease in its content. The data obtained indicated that in the period of puberty the ostriches intensively used GPx GSH to neutralize hydrogen peroxide and organic hydroperoxides. However, due to reduction of glutathione the transferase activity can accumulate toxic secondary products of the reaction of free radical oxidation of lipids and increase the protein with oxidized SH-groups.

One of the main antioxidants of blood plasma is CP. We founded that the CP concentration increased from the age of 9 months to the period of intensive egg laying, reached maximum values during the egg-laying peak. The increase in the number of $\mathrm{CP}$ during this period can be linked with its ability to transport $\mathrm{Cu}^{2+}$ into the oviduct for the formation of the yolk of the egg. The relatively 
stable content of $\mathrm{CP}$ in the serum of ostriches during the period of the study due to the high durability of this specific protein to the toxic effect of ROS, allowing it to maintain its biological activity in terms of their intensive generation. We revealed that at 18 months of age, LPO intensifies, the content of TBA-RS increases (Figure 4). The period of ostrich puberty was accompanied by an active course of anabolic processes, lipogenesis, which caused the accumulation of LPO products and decrease the activity of AOS enzymes during this period of bird growth.

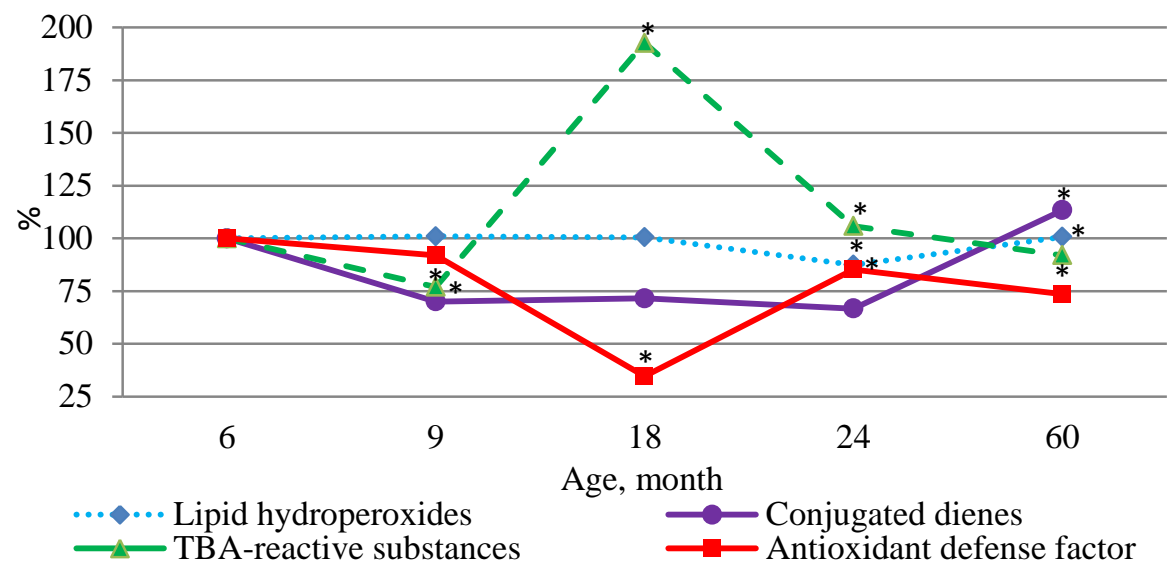

Figure 4. Age-related dynamics of ostrich lipid peroxidation products.

Activation of the processes of lipid peroxidation in the serum of ostriches of 60 months of age was in period of intensive egg laying, during which there was a maximum mobilization of metabolic processes aimed at the synthesis of the constituent components of the egg. An increase in the LHP and DC levels against the background of a decrease in the TBA-RS content indicated the impaired conversion of the primary LPO products. We determined the absolute values of lipid peroxidation intermediates and the ratio of their content to the level of the initial LPO substrates for a comprehensive assessment of the status of redox homeostasis (Figure 5).

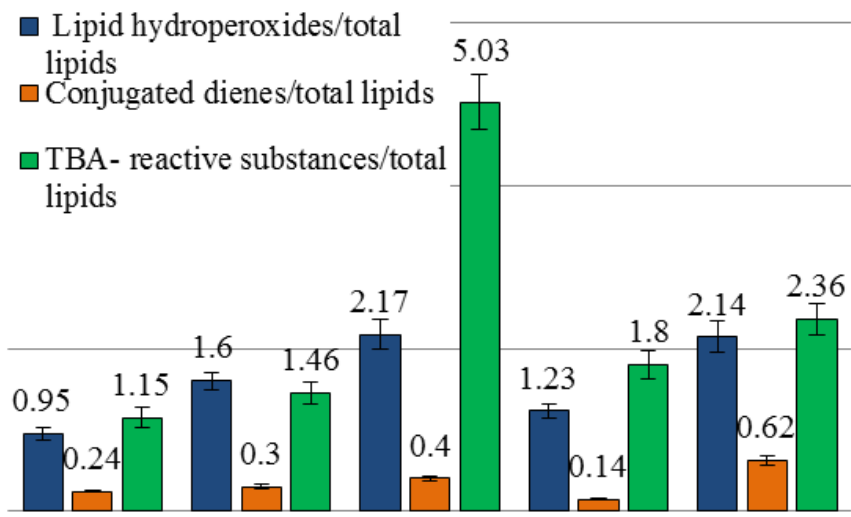

Age, month

Figure 5. The ratio of the content of products of lipid peroxidation to total lipids in the serum of ostriches.

The ratio LHP and TBA-RS total lipids in puberty birds was 2.28 and 4.37 times higher than in 6 -month-old birds. This indicated an intensification of lipid peroxidation processes on the background of reducing the content of total lipids. We registered a sharp decrease in the studied parameters in the egg-laying period.

The concentration of peroxide radicals in tissues largely depends on the content of GSH and activity of its dependent enzymes (Figure 6). Glutathione is the major non-protein thiol in bird and mammalian cells. It controls the redox balance, affects the synthesis of DNA and proteins, regulates the transmission of nerve signals, transcription and gene expression (García-Giménez et al., 2017). In the period from 6 to 18 months of age, GSH levels in serum is reduced in 2 times. The decrease in the content of reduced glutathione may be indicative of activation of compensatory mechanisms aimed at restoring and detoxify organic peroxides, which are actively formed in the reactions of free radical oxidation of lipids. The main target in such reactions are the unsaturated fatty acids of membrane phospholipids.

The conversion of lipid peroxides to neutral connection with the participation of glutathione is catalyzed by GPx. High affinity glutathione peroxidase to $\mathrm{H}_{2} \mathrm{O}_{2}$, and a significant availability of this substrate under the conditions of oxidation determines the probable growth $(27.7 \%)$ activity of this enzyme in puberty, but catalase activity in this period is the lowest. GPx, catalyzing the recovery of hydrogen peroxide, not only inactivates the metabolite, but also prevents the accumulation of hydroxyl-anion, preventing the formation of organic hydroperoxides. The restoration of glutathione peroxidase with organic hydroperoxides, especially lipid membranes, reduces peroxidation and the appearance of secondary toxic metabolites. In the period of intensive oviposition the activity of GPx decreased significantly compared with the beginning of this period. Increased activity glutathione enzymes at the beginning of oviposition reduces organic hydroperoxides and secondary products of LPO and is aimed at prevention of intensification of lipid peroxidation (Surai et al., 2019). The decrease in the content of TBA-RS against the background of increased activity of enzymes of antioxidant protection indicate that the serum of ostriches during the egg-laying period is characterized by a high level of antioxidant protection. 


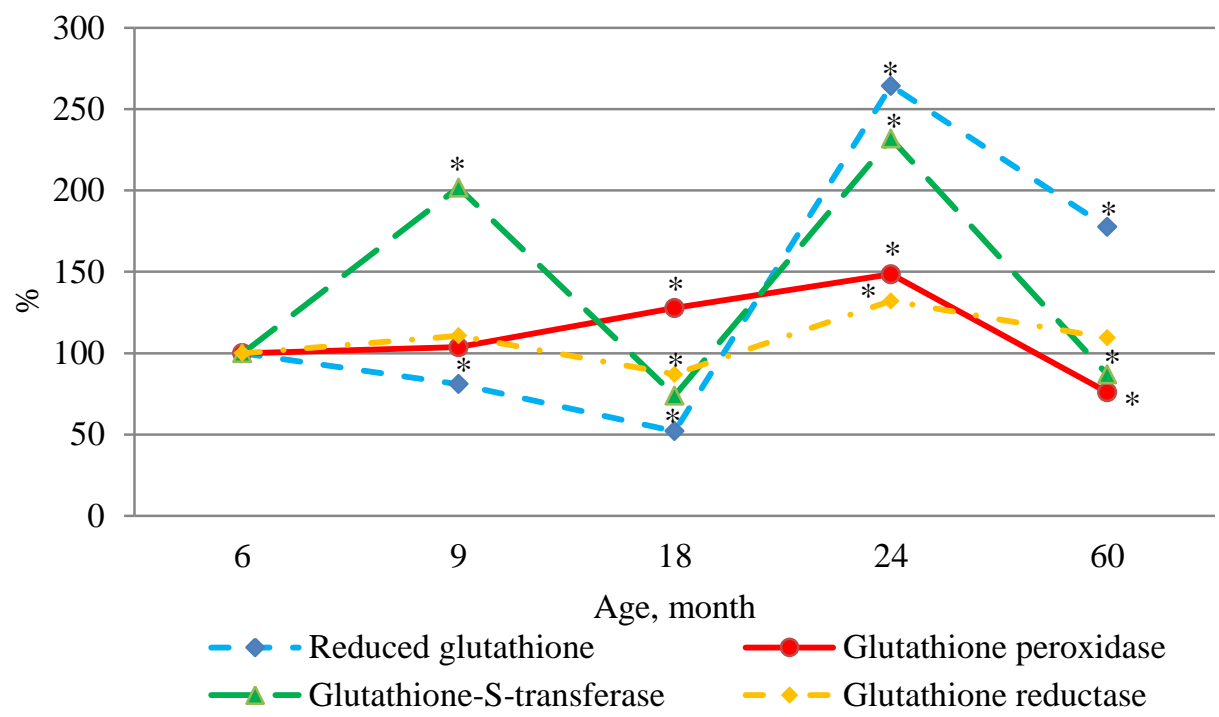

Figure 6. Age-related dynamics of reduced glutathione content and activity of glutathione-dependent enzymes.

GSH content increased by 2.6 and 1.7 times during the reproductive period, respectively, at the beginning and at the time of egg laying, the GRD activity also increased by 32.1 and $9.4 \%$, respectively compared to the previous study period. Oppression of glutathione reductase activity during puberty stage, on the background of increasing the activity of GPx shows that renewable power GRD is insufficient to exceed the rate of GSH utilization, so in this period there is an equilibrium shift in the redox cycle of glutathione in the direction of growth in intracellular oxidized glutathione. Low concentration of reduced glutathione in the serum of 18-months-old ostriches was explained by the active involvement of glutathione to antiradical and antiperoxide reactions of protection. In general, the standby power of glutathione antioxidant system of blood serum was sufficient to prevent a significant and prolonged decrease in the GSH content. Therefore, identified at the beginning of the reproductive period, increasing the activity of glutathione reductase and glutathione transferase and should be evaluated as a compensatory response aimed at restoring the contents of glutathione in serum. However, it is established that with age, the activity of GST and GPx in the serum of ostriches is reduced. This is probably due to the depletion of the antioxidant system, which is typical for other species of animals and birds. The data obtained indicated a close correlative connection between the intensity of LPO and the activity of enzymes of system of antioxidant protection. During study period, we established negative correlation between the content of LHP and GPx activity ( $r=-$ $0.83)$, LHP and GST ( $r=-0.74)$, LHP and CAT $(r=-0.78)$, TBA-RS and GRD ( $r=-0.79)$, TBA-RS and CAT ( $r=-0.74)$. Thus, we noted high correlation between the DC and GSH $(r=0.71)$, DC and CP $(r=0.90)$, TBA-RS and SOD ( $r=0.82)$ (Figure 7). Intensification of processes of lipid peroxidation is accompanied by a compensatory increase in the activity of superoxide dismutase, glutathione peroxidase and content of ceruloplasmin. Recorded a decrease of GSH content and inhibition of the activity of CAT and GST.

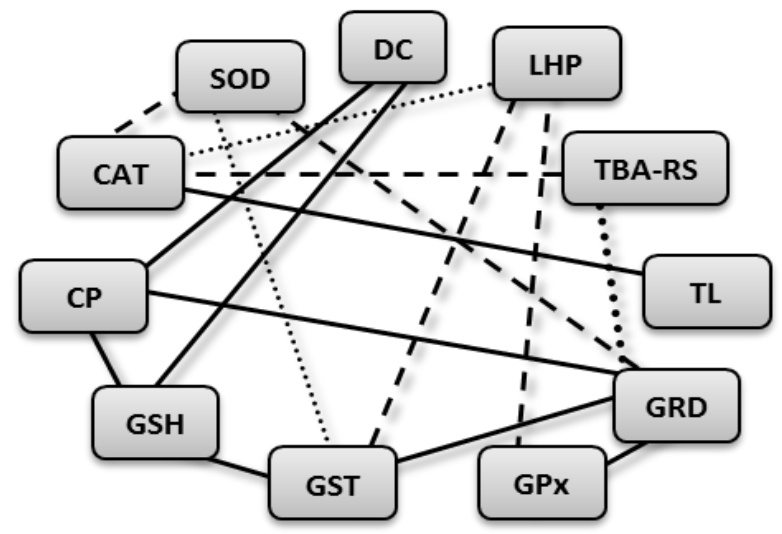

Figure 7. Correlative links between antioxidant enzyme activity, content of lipid peroxidation product, and total serum lipids. Moderate link $\longrightarrow(0.5<r<0.7)$; strong $-(0.7<r<1.0)$; negative moderate $\ldots . . . .(-0.5<4<-0.7)$; -- negative strong $(-0.7<r<-1.0)$.

\section{Conclusion}

We revealed that the content of total lipids in the dough correlates with the processes of lipid peroxidation and the functioning of the antioxidant system. Each period ostrich life cycle had specific intensity of the antioxidant system and the accumulation of intermediate products of lipid peroxidation. The period of puberty in ostriches was accompanied by an intensification of lipid peroxidation in the blood serum. This is confirmed by a significant increase in the number of TBA-reactive substances, which could be explained by the insufficient activity of enzymes of the antioxidant system (catalase, glutathione-S-transferase, glutathione reductase). We registered that the peak of the oviposition is characterized by increased metabolism in the body, which causes the activation of free radical oxidation. At the same time, the concentration of lipid hydroperoxides and diene conjugates increased, while TBA-reactive substances was not significantly changed. We suggested that the antioxidant protection in ostrich blood during this period was determined by significant concentration of ceruloplasmin and reduced glutathione, which is probably provided by 
increasing the activity of glutathione reductase. Therefore, puberty and the intensive period of oviposition in ostriches can be characterized as periods of tension in metabolic processes with increased intensity of lipid oxidation, which is associated with certain changes in the physiological and functional state of bird organisms.

\section{References}

Alam, M. N., Bristi, N. J., \& Rafiquzzaman, M. (2013). Review on in vivo and in vitro methods evaluation of antioxidant activity. Saudi Pharmaceutical Journal, 21(2), 143-152. doi.org/10.1016/j.jsps.2012.05.002.

Al-Khalifa, H., \& Al-Naser, A. (2014). Ostrich meat: Production, quality parameters, and nutritional comparison to other types of meats. Journal of Applied Poultry Research, 23(4), 784-790. doi.org/10.3382/japr.2014-00962.

Andreeva, L. I., Kozhemyakin, L. A., \& Kishkun, A. A. (1988). Modifikaciya metoda opredeleniya perekisej lipidov v teste s tiobarbiturovoj kislotoj. Laboratornoe delo, 11(41), 41-44. (in Russian).

Bastos, M. S., Del Vesco, A. P., Santana, T. P., Santos, T. S., de Oliveira Junior, G. M., Fernandes, R. P. M., \& Gasparino, E. (2017). The role of cinnamon as a modulator of the expression of genes related to antioxidant activity and lipid metabolism of laying quails. PloS one, 12(12), e0189619. doi:10.1371/journal.pone.0189619.

Bejaei, M., \& Cheng, K. M. (2014). Effects of pretransport handling stress on physiological and behavioral response of ostriches. Poultry science, 93(5), 1137-1148. doi.org/10.3382/ps.2013-03478.

Beregovij, V. K. (2012). Strausivnictvo yak perspektivna galuz tvarinnictva. Agrosvit, (11), 29-32.

Bityutskyy, V., Tsekhmistrenko, S., Tsekhmistrenko, O., Melnychenko, O., \& Kharchyshyn, V. (2019). Effects of Different Dietary Selenium Sources Including Probiotics Mixture on Growth Performance, Feed Utilization and Serum Biochemical Profile of Quails. In Modern Development Paths of Agricultural Production (pp. 623-632). Springer, Cham. https://doi.org/10.1007/978-3-030-14918-561.

Brand, T. S., Kritzinger, W. J., van der Merwe, D. A., Muller, A., Hoffman, L. C., \& Niemann, G. J. (2018). Feather and skin development of ostriches Struthio camelus. Journal of the South African Veterinary Association, 89(0), e1-e5. doi:10.4102/jsava.v89i0.1556.

Burlaka, A., Tsybulin, O., Sidorik, E., Lukin, S., Polishuk, V., Tsehmistrenko, S., \& Yakymenko, I. (2013). Overproduction of free radical species in embryonal cells exposed to low intensity radiofrequency radiation. Experimental oncology, 35(3), $219-225$.

Cai, C. H., Zhao, R. X., Wang, P., Wang, J. S., Li, K. X., Zhan, X. A., \& Wang, K. Y. (2019). Effects of different stocking densities on growth performance, antioxidant ability, and immunity of finishing broilers. Animal Science Journal, 90(4), 583-588. doi: 10.1111/asj.13148.

Chevari, S., Andyal, T., \& Shtrenger, Ya. (1991). Opredelenie antioksidantnyh parametrov krovi i ih diagnosticheskoe znachenie v pozhilom vozraste. Laboratornoe delo, 10, 9-13. (in Russian).

Chevari, S., Chaba, I., \& Sekej, J. (1985). Rol superoksiddismutazy v okislitelnyh processah kletki i metod opredeleniya ee v biologicheskih materialah. Laboratornoe delo, 11, 678-680. (in Russian).

Cloete, S. W. P., Engelbrecht, A., Olivier, J. J., \& Bunter, K. L. (2008). Deriving a preliminary breeding objective for commercial ostriches: an overview. Australian Journal of Experimental Agriculture, 48(10), 1247-1256.

Del Vesco, A. P., Khatlab, A. S., Goes, E. S., Utsunomiya, K. S., Vieira, J. S., Oliveira Neto, A. R., Gasparino E. (2017). Age-related oxidative stress and antioxidant capacity in heat-stressed broilers. Animal: An International Journal of Animal Bioscience., 11(10), 1783-1790. doi: 10.1017/S1751731117000386.

Fernye, C., Ancsin, Z., Bócsai, A., Balogh, K., Mézes, M., \& Erdélyi, M. (2018). Role of glutathione redox system on the T-2 toxin tolerance of pheasant (Phasianus colchicus). Toxicological research, 34(3), 249-257. doi:10.5487/TR.2018.34.3.249.

Fisinin, V. I., Kavtarashvili, A. Sh., \& Kolokolnikova, T. N. (2014). Kak borotsya s teplovym stressom pticy?. Pticevodstvo, (6), 2-11. (in Russian).

Forrester, S. J., Kikuchi, D. S., Hernandes, M. S., Xu, Q., \& Griendling, K. K. (2018). Reactive oxygen species in metabolic and inflammatory signaling. Circulation research, 122(6), 877-902. doi:10.1161/CIRCRESAHA.117.311401.

García-Giménez, J. L., Romá-Mateo, C., Pérez-Machado, G., Peiró-Chova, L., \& Pallardó, F. V. (2017). Role of glutathione in the regulation of epigenetic mechanisms in disease. Free Radical Biology and Medicine, 112, 36-48. doi: 10.1016/j.freeradbiomed.2017.07.008.

Ghasemi, H., \& Hajkhodadadi, I. (2019). Metabolic profile and antioxidant status of ostriches receiving water supplemented with essential oil mixture of Zataria multiflora, Mentha piperita, Foeniculum vulgare and Eucalyptus globules. Iranian Journal of Medicinal and Aromatic Plants Research, 35, 1(93). 12-24.

Goryachkovskij, O. M. (1998). Opredelenie urovnya vosstanovlennogo glutationa v eritrocitah krovi. Klinicheskaya biohimiya: Spravochnoe posobie-Odessa: Astroprint, 370-372. (in Russian).

Goth, L. (1991). A simple method for determination of serum catalase activity and revision of reference range. Clinica chimica acta, 196(2-3), 143-151. doi.org/10.1016/0009-8981(91)90067-M.

Habig, W. H., Pabst, M. J., \& Jakoby, W. B. (1974). Glutathione S-transferases the first enzymatic step in mercapturic acid formation. Journal of biological Chemistry, 249(22), 7130-7139.

Jóźwik, A., Poławska, E., Zdanowska-Sąsiadek, Ż., Lipińska, P., Kawka, M., Guzek, D., \& Strzałkowska, N. (2015). Oxidative stability of ostrich meat related to duration of linseed and lucerne supplementation to the bird's diet. Bulletin of the Veterinary Institute in Pulawy, 59(1), 79-83.

Krylatov, A. V., Maslov, L. N., Voronkov, N. S., Boshchenko, A. A., Popov, S. V., Gomez, L., Wang, H, Jaggi, A. S., \& Downey, J. M. (2018). Reactive oxygen species as intracellular signaling molecules in the cardiovascular system. Current cardiology reviews, 14(4), 290-300. doi:10.2174/1573403X14666180702152436.

Magige, F., \& Røskaft, E. (2017). Medicinal and commercial uses of ostrich products in Tanzania. Journal of ethnobiology and ethnomedicine, 13(1), 48. doi:10.1186/s13002-017-0176-5.

Mahrose, K., Elsayed, M., Basuony, H., \& Gouda, N. (2016). Effects of exposing ostrich eggs to doses of gamma radiation on hatchability, growth performance, and some blood biochemicals of hatched chicks. Environmental Science and Pollution Research, 23(22), 23017-23022. doi:10.1007/s11356-016-7539-7.

Minka, N. S., \& Ayo, J. O. (2008). Assessment of the stresses imposed on adult ostriches (Struthio camelus) during handling, loading, transportation and unloading. Veterinary record, 162(26), 846-851. 
Morosinotto, C., Rainio, M., Ruuskanen, S., \& Korpimäki, E. (2018). Antioxidant Enzyme Activities Vary with Predation Risk and Environmental Conditions in Free-Living Passerine Birds. Physiological and Biochemical Zoology, 91(3), 837-848. doi: $10.1086 / 697087$.

Nagorna, L. V. (2013). Ektoparazitofauna u strausivnichih gospodarstvah pivnichno-shidnogo regionu Ukrayini. Agrarnij visnik Prichornomor'ya. Veterinarni nauki, (68), 197-200. (in Ukrainian).

Ravin, H. A. (1961). Secretion of digestive enzyme by pancreas with minimal transit tisue. Journal of Laboratory and Clinical Medicine, 58, 161-168.

Rehman, Z. U., Meng, C., Sun, Y., Safdar, A., Pasha, R. H., Munir, M., \& Ding, C. (2018). Oxidative Stress in Poultry: Lessons from the Viral Infections. Oxidative medicine and cellular longevity, 2018, 5123147.

Romanova, L. A., \& Stalnaya, I. D. (1977). Metod opredeleniya gidroperekisej lipidov s pomoshyu tiocionata ammoniya. Sovremennye metody v biohimii, 64-66. (in Russian).

Roy, J., Galano, J. M., Durand, T., Le Guennec, J. Y., \& Lee, J. C. Y. (2017). Physiological role of reactive oxygen species as promoters of natural defenses. The FASEB Journal, 31(9), 3729-3745. doi: 10.1096/fj.201700170R.

Ryeznikov, O. G. (2003). Zagalni etichni principi eksperimentiv na tvarinah. Endokrinologiya, 8(1). 142-145. (in Ukrainian).

Scanes, C. G. (2016). Biology of stress in poultry with emphasis on glucocorticoids and the heterophil to lymphocyte ratio. Poultry science, 95(9), 2208-2215. doi.org/10.3382/ps/pew137.

Stalnaya, I. D. (1977). Metod opredeleniya dienovoj konyugacii nenasyshennyh vysshih zhirnyh kislot. Sovremennye metody v biohimii, 63-64. (in Russian).

Surai, P. F., Kochish, I. I., Fisinin, V. I., \& Kidd, M. T. (2019). Antioxidant Defence Systems and Oxidative Stress in Poultry Biology: An Update. Antioxidants, 8(7), 235. doi:10.3390/antiox8070235.

Tsekhmistrenko, S \& Polishchuk, V. (2010). Age-related peculiarities of antioxidant system functioning in the blood of ostriches. Ukrainskil biokhimicheskiĭ zhurnal, 82, 92-97 (in Ukrainian).

Tsekhmistrenko, S. I., Bityutskyy, V. S., Tsekhmistrenko, O. S., Polishchuk, V. M., Polishchuk, S. A., Ponomarenko, N. V., Melnychenko, Y. O., \& Spivak, M. Y. (2018a). Enzyme-like activity of nanomaterials. Regulatory Mechanisms in Biosystems, 9(3), 469-476. https://doi.org/10.15421/021870.

Tsekhmistrenko, O. S., Tsehmistrenko, S. I., Bityutskyy, V. S., Melnichenko, O. M., Oleshko, O. A. (2018b). Biomimetic and antioxidant activity of nano-crystaline cerium dioxide. World of Medicine and Biology, 1(63), 196-201. DOI 10.267254/2079-83342018-1-63-196-201 (In Ukrainian).

Vazquez-Galindo, G., de Aluja, A.S, Guerrero-Legarreta, I., Orozco-Gregorio, H., Borderas-Tordesillas, F., Mora-Medina, P., RoldanSantiago, P., Flores-Peinado, S., Mota-Rojas, D. (2013). Adaptation of ostriches to transport-induced stress: physiometabolic response. Animal Science Journal, 84(4), 350-358. doi: 10.1111/asj.12010.

Wan, X. L., Ju, G. Y., Xu, L., Yang, H. M., \& Wang, Z. Y. (2019). Dietary selenomethionine increases antioxidant capacity of geese by improving glutathione and thioredoxin systems. Poultry science, 98 (9), 3763-3769. doi.org/10.3382/ps/pez066.

Yusupova, L. B. (1989). O povyshenii tochnosti opredeleniya aktivnosti glutationreduktazy eritrocitov. Laboratornoe delo, 4(19-21), 13. (in Russian).

\section{Citation:}

Polishchuk, V.M., Tsekhmistrenko, S.I., Polishchuk, S.A., Ponomarenko, N.V., Rol, N.V., Cherniuk, S.V., Cherniavskyi, O.O., Kuzmenko, O.A., Prysiazhniuk, N.M., Karaulna, V.M., Lastovska, I.O., Fedoruk, N.M. (2020). Age-related characteristics of lipid peroxidation and antioxidant defense system of ostriches (Struthio camelus domesticus). Ukrainian Journal of Ecology, 10(1), 168-174.

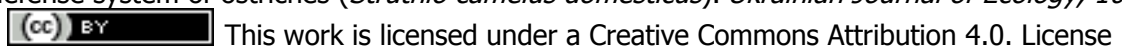

